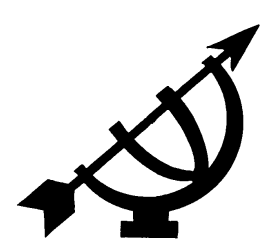

\title{
Ensuring coherence: two solutions to organising poetic language ${ }^{1}$
}

\author{
A. Weideman \\ Department of English \\ University of the Free State \\ BLOEMFONTEIN \\ E-mail: albert.weideman@ufs.ac.za
}

\begin{abstract}
Ensuring coherence: two solutions to organising poetic language
\end{abstract}

The organisation of poetic language as discourse type and as text is worth considering in its own right. What do poets bring to expression through their organisation of language, and how do they do it, if they employ language skilfully in order to support the main discursive threads of their work? This contribution demonstrates that poets may choose to organise language around discursive threads in order to ensure the integrity or wholeness of their texts. We might also label this wholeness the aesthetic coherence of the poetry that is produced. The article discusses two examples of how poets ensure coherence by organising their language in highly specific and inventive ways.

\section{Opsomming}

\section{Om koherensie te verseker: twee oplossings vir die organisasie van poëtiese taal}

Dit is die moeite werd om die organisatoriese aspek van poetiëse taal as volwaardige diskoers- en teksvorm te oorweeg. Wat bring digters tot uitdrukking in die manier waarop hulle taal

1 I would like to thank our research assistant, Colleen du Plessis, for editorial suggestions, and following up and updating numerous references for me, as well as contributing substantially to the translation and remodelling of two analyses that were published years ago in a now obscure publication that is no longer available. Thanks, too, to Margaret Raftery, who encouraged me to consider recasting and relating them to my recent work, and to Manuela Lovisa, who pointed us in the right direction when we needed professional advice. 
organiseer; en hoe bewerkstellig hulle dit indien hulle taal vernuftig aanwend sodat die diskursiewe draad van die teks deurlopend ondersteun word? Hierdie bydrae illustreer hoe digters, in die organisering van hulle poëtiese taalgebruik, keuses maak om hulle taal so aan te wend dat diskursiewe lyne die koherensie en integriteit van hulle tekste verseker. Hierdie soort samebinding sou estetiese koherensie genoem kon word. Die artikel bespreek twee voorbeelde van poëtiese koherensie aan die hand van verskeie digters se hoogs innoverende en doelgerigte organisering van taal.

\section{Material types of discourse and factual texts}

The theory of material lingual spheres or discourse types set out in Weideman (2009:39 ff.) has not yet been widely tested. The theory posits that there are differences in content - or material differences - among various discourse types, and that these are never adequately explained by linguistic theory, especially if the latter utilises only a general notion of the lingual modality of experience (Weideman, 2011). Instead, a responsible linguistic analysis should examine how the lingual is embedded in concrete language use, which in its turn is typified by the nature of each discourse type. As will be demonstrated, the lingual modality is disclosed and creatively opened up by such typically distinct employment. This theoretical starting point means that the differences among typically different kinds of factual language found within discourse types or material lingual spheres can, furthermore, never be adequately conceptualised with reference only to formal (lexical or syntactic) features:

... the difference in content between these various types of language soon leads one to discover not only objective, formal differences, but also various typical norms and principles that give a different content to the factual language used within such a typical sphere (Weideman, 2009:40).

Put differently: a purely linguistic analysis - if that were possible - is never enough (Weideman, 2011).

This contribution will examine some typical characteristics of poetry identified in light of these distinctions to test the scope of the theory outlined above. The further question, however, is: If it is possible to discover unique features in the language of poetry, is it not equally possible that those unique features somehow still find expression in the formal, factual organisation of the poetic text? 
When linguistic analysis moves beyond the analysis of formal linguistic units (phonemes, morphemes, lexemes, phrases and clauses), it utilises sociolingual units of analysis such as (typical types of) discourse as normative conditions for language, and on the factual side of the lingual mode, text (Weideman, 2010: ch. 3 \& 4).

Text can be defined as the objective linguistic form of social interaction, hence as a communicative occurrence (Halliday, 1978:122; De Beaugrande \& Dressler, 1981:3). In an early discussion of what makes a text a text - criteria that a text must fulfil in order to be a text - De Beaugrande and Dressler $(1981 ;$ 2002) discuss several standards of textuality. These include the standards of cohesion and coherence, which are considered objective and text-centred criteria. More than any of the other criteria, cohesion and coherence define the wholeness or unity of a text. Both deal with the continuity or connectedness of texts, but cohesion is a term that is usually reserved for verbally explicit connectedness, while coherence is used to indicate a non-verbally explicit connectedness that depends on a shared knowledge of the world and the texts that reflect this (cf. Weideman, 2010:53). However, coherence can extend beyond its usual application of incorporating exophoric reference and allusiveness, to an organisational level sometimes overlooked. The aim of this contribution is to illustrate this by examining some examples from poetry, and to show how poets may choose to organise language around discursive threads in order to ensure the integrity or wholeness of their texts. For the sake of focus and brevity, the analysis below will not consider cohesion in the technical sense - as defined by Halliday and Hasan (1976:10 ff.) - as verbally explicit connectedness, since that is a linguistic concept that is limited to formal (lexical and syntactic) ties among various elements of texts.

\section{Aesthetic coherence in poetic texts}

A first sense of non-verbally explicit continuity is conventionally to be gained by orienting to the progression one may observe in a poetic text. The aspect of progression from one particular state to another is particularly noticeable, for example, in poetry that communicates a progression in the face of adversity, from personal struggle or loss to acceptance. Among the Afrikaans poets Totius, in the first part of Skemering (1948), the poem entitled "Die donker poort" (The dark gateway), provides a typical example of how poets struggle to respond to loss - proceeding from a sense of calamity to one of anxiety, and subsequently experiencing acceptance. After a struggle, sorrow is eventually conquered. The same kind of progression is 
noted by critics (cf. Nardo, 1979:19-20) in Milton's sonnet "On his blindness" as he progresses from heartbreak, through doubt, towards acquiescence:

When I consider how my light is spent

Ere half my days in this dark world and wide

And that one talent which is death to hide

Lodged with me useless, though my soul more bent

To serve therewith my Maker, and present

My true account, lest He returning chide,

"Doth God exact day-labour, light denied?"

I fondly ask. But Patience, to prevent

That murmur, soon replies, "God doth not need

Either man's work, or His own gifts. Who best

Bear His mild yoke, they serve him best. His state

Is kingly: thousands at his bidding speed

And post o'er land and ocean without rest:

They also serve who only stand and wait."

The presence of this line of development (calamity and sorrow, struggle and acceptance) is uncontested ("fondly", incidentally means "foolishly"). In his active forties, Milton goes blind, and, in the utterly disciplined format of a sonnet, depicts for us his faltering, hesitant steps, his wrestling with the disaster that he has yet to understand, eventually to find peace.

Of course there are further dimensions to the sorrow-anxiety-acceptance line if one looks more closely, even more so because poetic language is characteristically allusive and multidimensional. Like a Persian lute with its seven main strings that cause the other eleven to vibrate sympathetically, this kind of language creates reverberations of aesthetic meaning that echo, in undertones and overtones, the multiplicity of connotations in its diction.

Applied to Milton's sonnet, we observe the following: light in the first line does not merely denote eyes or (eye)sight, nor is it employed as term solely to contrast sharply with the dark world evoked in the second line. In Milton's work this is associated almost invariably with God's deeds of creation (as in Gen. 1:3). Compare, for example, the following two excerpts from his "Samson Agonistes" (Reeves, 1972: $108 \mathrm{ff}$.$) :$

O Loss of sight, of thee I most complain!

Blind among enemies, $O$ worse than chains,

Dungeon or beggary, or decrepit age!

Light, the prime work of God, to me is extinct ... 
and

O first-created beam, and thou great Word,

'Let there be light, and light was over all,'

Why am I thus bereaved thy prime decree?

It would be cynical, in my judgement, to ascribe this merely to a struggle within Milton, of an inclination by him towards neo-Platonic ideas. What seems to me to be more important is that the discursive thread sustained by the line of grief-doubt-rest, is supported by another: a line that begins with creation, falters as an effect of rebelliousness ("That murmur"), and finds its denouement in the expectant waiting upon the Lord (as in Ps. 27:14), its fulfilling point of culmination.

There is very little passivity, we should note, in the expectant acquiescence of the final line of the poem; it seems to be nothing less, for this Christian poet, than the expectation of Christ's return, as in Revelation 20:22. What we have here, in other words, is a progression from Genesis ("light", "first-created beam") to Revelation a bracketing not only of the limits of human existence, as seen by the devout, but of the main contours of human experience: creation, the fall into sin, and redemption. This seems to be the key to understanding the poem, and the one that unlocks its depth and rich allusiveness.

It is exactly this theme, of creation-rebellion-redemption, that defines the confessional undertones of the poem - and not in the first instance the obvious biblical allusion to, for example, the parable of the talents (Matt. 25:4-30), nor any of the other biblical references. Indeed, the use of the parable of the talents, if we read closely, is intended as a rationalisation on the theme of that tale, an argument against the essence of the underlying confession. The exploration and the further disclosure of the latter, it appears to me, are much more relevant when we consider the poem as an aesthetically wellorganised whole, rather than a discussion of whether it was written in 1655 or 1651, or even in 1652 (cf. Nardo, 1979:146).

The discursive thread that we articulate by drawing attention to the line of creation-sin-redemption in Milton's poem is of course a theoretical formulation of what we suspect underlies the poem. We discover it by patiently uncovering what the poet presents us with through devices of allusion and suggestion. Within the poem, such crass and blatant formulation is disallowed. It takes the genius of an Aristotle or Kant to formulate the basic themes that underlie their 
thinking in the formulas of, respectively, form and matter, and nature and freedom. For the artist and poet Milton, such patent formulations would no doubt contradict the typicality of poetic language that he is aesthetically exploiting here, yet Milton's basic theme is there, awaiting its discovery.

If the nature of poetic language is aesthetically specific, and different, thus, from other types of discourse, it would also be worth our while to consider how, in the organisation of this poem, Milton converts the Italian (Petrarchan) sonnet, and transforms it into something essentially different. As in the Petrarchan, we have a whollydisciplined rhyme scheme: abba abba in the octave, and cde cde in the sestet. Unlike the Italian format, however, we find in Milton's poem that there is enjambment between octave and sestet: the first literally runs into the second. This is exceptional, since in the work of many other poets this was felt to be a necessary split (cf. Nardo, 1979:158-162). The division between octave and sestet was a handy device to echo the divide, for example, between nature and freedom, a theme that is antithetical to Milton's confessional basis. Could it be that Milton's coherent discursive thread (the theme of creation-sin-redemption) has enabled him intuitively to short-circuit such a division, and to use a device like enjambment to ensure the wholeness of the text? As one reviewer has pointed out, while we are aware of research on the relationship between thematic content and worldview, it is truly remarkable to find a connection between belief and the formal organisation of poetic language. Yet it echoes a point within reformational scholarship, that is the hallmark of this journal, namely that there is a strong link between faith and human action.

If that connection holds, then Wellek and Warren's (1949:235) pronouncement that "... he [Milton] knew how to adjust, stretch, alter the classical forms - knew how to Christianize and Miltonize ..." gains new meaning in light of his sonnets. What is more, in that case the apparently most trivial device (in this case: enjambment) can be explored more fully only when we have unearthed the underlying theme of his poetry. Figure 1 summarises the ways, examined thus far, in which the poet ensures coherence and unity. 
Figure 1: Thematic unity and coherence

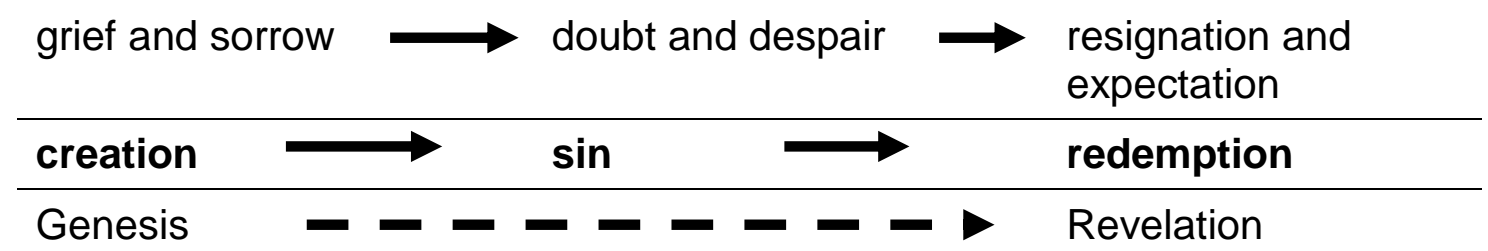

But Milton's organisation of language within this poem to ensure its wholeness goes much further. Consider, for example, how the poem is bracketed additionally by the format of the first four lines echoing the content of the last four, achieving a coherence through the unity of form and content:

When I consider how my light is spent Ere half my days in this dark world and wide And that one talent which is death to hide Lodged with me useless, though my soul more bent

To serve therewith my Maker, and present My true account, lest He returning chide, "Doth God exact day-labour, light denied?" I fondly ask. But Patience, to prevent

That murmur, soon replies, "God doth not need Either man's work, or His own gifts. Who best Bear His mild yoke, they serve him best. His state Is kingly: thousands at his bidding speed And post o'er land and ocean without rest: They also serve who only stand and wait."

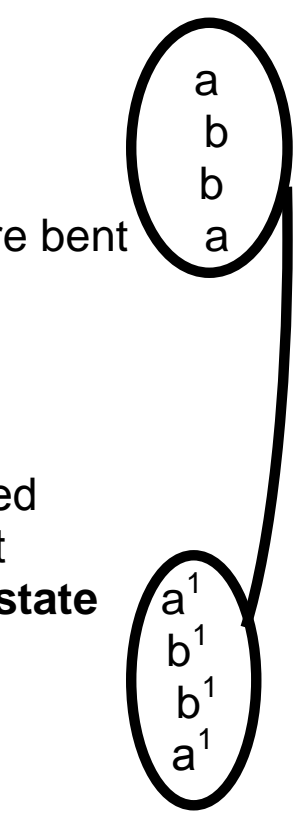

Here the form of the rhyme scheme (abba) is reflected in the content $\left(a^{1} b^{1} b^{1} a^{1}\right)$ of the last four lines, where $a^{1}=$ lack of motion and $b^{1}=$ energetic, purposeful motion:

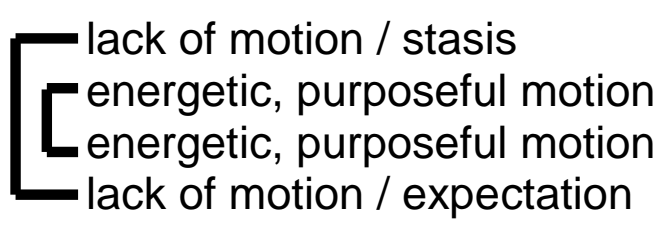

Consider next John Donne's Batter my heart, presumably written in the year 1609 (Gardner, 1972:83). Donne too has converted the conventional Italian sonnet format into something unique by changing the rhyme scheme of the sestet ( $c d c d e e)$. We find in this sonnet, furthermore, the same kind of bracketing and organisation to support the discursive thread, as that detected in Milton's poem: 
Batter my heart, three person'd God; for you

As yet but knocke, breathe, shine, and seek to mend;

That I may rise, and stand, o'erthrow mee, 'and bend

Your force, to breake, blowe, burn and make me new.

I, like an usurpt towne, to'another due

Labour to 'admit you, but Oh, to no end,

Reason, your viceroy in mee, mee should defend,

But is captive'd, and proves weake or untrue,

Yet dearly "I love you, and would be lov'd faine,

But am betroth'd unto your enemie,

Divorce mee, 'untie, or brake that knot againe,

Take mee to you, imprison mee, for I

Except you 'enthrall mee $\left(a^{1}\right)$, never shall be free $\left(b^{1}\right)$

Nor ever chast $\left(b^{1)}\right.$, except you ravish mee $\left(a^{1)}\right.$.

Where $a^{1} b^{1} b^{1} a^{1}$ is:

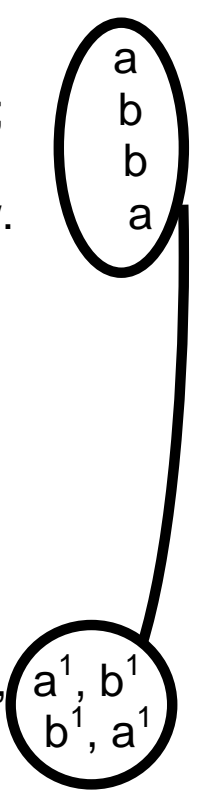

\footnotetext{
enslavement

desirable state (freedom)

desirable state (chastity)

violent captivity
}

Before returning below to a discussion of this remarkable form of poetic organisation, we may note, first, that already in the opening three words we find a strange union between warfare and romance, freedom and enslavement - the discursive thread which runs through the poem. Donne, the soldier, desperately fights for freedom, but Donne, the lover, is held captive by the enemy. In the first quatrain we hear the violent breaching sounds of warfare expressed in the explosive and staccato "breake, blowe, burn" - such is the extent of the violence needed to break through the fortifications of the town (heart) occupied by the enemy (wrong lover). The alliteration of the three infinitives is cohesively tied to the "three person'd God" in line one; three persons are needed to carry out the three actions, so intense is the captivity. The lawful ruler of man's heart has been deposed by the armies of darkness. Whereas Aquinas advocated that it was the innocence of natural reason that led man to the threshold of grace, Donne finds this "viceroy" of reason to be weak and incapable of providing protection against the clutches of the enemy. It is Donne the preacher, who can be heard in the allusiveness of the second quatrain, which resonates with the cries of the apostle Paul in Romans 7:23-24. Here Paul describes himself as a wretched man waging a war in his mind that keeps him captive to the law of sin. 
The military imagery is followed by a declaration of love in the sestet resembling that expressed in a tragic love triangle. This is followed by an appeal for divorce and remarriage in a paradox of violent and almost shocking imagery, typical of religious metaphysical poetry of the time (cf. Jones, 1977:89).

Once again, as in Milton's poem, the organisation of the sonnet masterfully supports its contents. We see the fragility of the relationship with the true lover supported by the strong-lined metaphysical style and "concise-expression, achieved by an elliptical syntax" (Gardner, 1972:17). The hesitant, jolting, staccato-like phrases and punctuation thus provide further coherence in terms of structure and theme. Examine the following three lines:

As yet but knocke, breathe, shine, and seek to mend;

That I may rise, and stand, o'erthrow mee, 'and bend

Your force, to breake, blowe, burn and make me new.

The hesitant, stop-start movement is counteracted by using enjambment in line three. This contrastive effect is repeated in the last part of the poem with further enjambment in the twelfth line. Moreover, the contrasting rhyme scheme in the octave (abba abba) fully cooperates with the contrasting theme of the poem. In the first quatrain, lines one and four parallel the content: line one expresses the violent measures sought $(a)$, while line four provides the detail of the violence $(a)$. Lines two $(b)$ and three $(b)$ are parallel in terms of content expressing the non-violent ineffectual measures of God and the non-violent actions of man.

Again, as in Milton, content echoes organisation or form, and the same remarkable connection between conviction and the formal organisation of poetic language is evident in Donne's work (also see below), especially in the employment of paradox.

What would one make of the ironic contrasts we find in lines seven and eight? The representative viceroy should protect (1. 7), but is too weak (I. 8), an effect which is repeated in lines nine and ten: love is proclaimed (I. 9), but love is impossible (I. 10). Contrast is also created in the unexpected order found in line three: first the effect is provided, and thereafter the cause: 
That I may rise, and stand

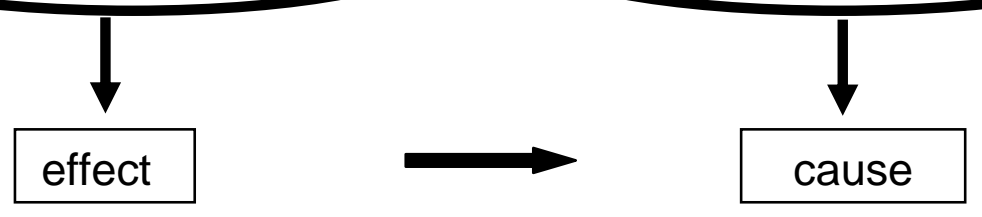

o'erthrow mee, 'and bend

The vertical congruence is broken through by the horizontal contrast in the form of a paradox: if you want to stand up, you need to be overthrown (I. 3); if you want to experience renewal, you have to be destroyed forcefully. The denouement comes in the symmetrical couplet at the conclusion of the sonnet with the ultimate paradox:

Except you 'enthrall mee, \|n never shall be free,

b

a

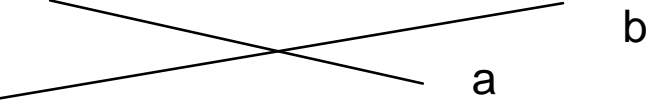

Nor ever chast, || except you ravish mee.

Irony is evident in the collocation of the word chast with ravish. By being defiled (ravished), one can be rendered pure (chaste). Donne strikes a blow at the humanistic division between freedom and slavery by employing the epitome of a paradox: if one is not the bondservant of the Most High, one is not free, but a slave to sin. Freedom thus does not exclude bondage. The two are in fact synonymous or at least mutually inclusive. That is the crux of the poem and an exophoric reference to 1 Corinthians 7:21-22, which reads that those who are called while a slave are the Lord's freedmen. Likewise, those who are called while free, are Christ's slaves. Human freedom is secured once we are slaves.

\section{Conclusion}

As in the case of Milton's On his blindness, we see thematic unity and coherence in the organisation of Donne's Batter my heart. The same kind of bracketing is achieved in the format of the opening quatrain and the couplet at the end, with the format and content of the paradoxical last two lines echoing the artistry and form of the first four.

We may therefore conclude that the language used by both poets is worth examining, because its organisation not only supports, in a multiplicity of ways, the discursive thread of their work, but also reflects a connection between convictions and factual language use. Both poetic texts provide demonstrations of a deliberately allusive, 
referential, multilayered and inventive aesthetic coherence. A further implication is that, though discourse types may be materially different, those differences also find expression in the factual organisation of language. In the case of the texts examined here, their typicality nonetheless appears to derive from the aesthetic function that characterises poetic texts. If, as was claimed at the outset, linguistic analysis can never be enough, it would also be appropriate to conclude positively, by noting that the lingual dimension of experience which defines the analytical domain of linguistics (Weideman, 2011) - is enlivened and creatively disclosed by its typically aesthetic employment within the discourse type examined above.

\section{List of references}

DE BEAUGRANDE, R.A. \& DRESSLER, W.U. 1981. Introduction to text linguistics. London: Longman.

DE BEAUGRANDE, R.A. \& DRESSLER, W.U. 2002. Introduction to text linguistics. Digitally reformatted. http://www. beaugrande.com/introduction text linguistics.htm Date of access: 5 Jul. 2011.

GARDNER, H. 1972. The metaphysical poets. London: Penguin.

HALLIDAY, M.A.K. 1978. Language as social semiotic: the social interpretation of language and meaning. London: Arnold.

HALLIDAY, M.A.K. \& HASAN, R. 1976. Cohesion in English. London: Longman. JONES, E. 1977. Authors in their age. Glasgow: Blackie.

NARDO, A.K. 1979. Milton's sonnets and the ideal community. Lincoln: University of Nebraska Press.

TOTIUS, 1948. Skemering. Kaapstad: Nasionale Pers.

WEIDEMAN, A. 2009. Beyond expression: a systematic analysis of the foundations of linguistics. Grand Rapids: Paideia.

WEIDEMAN, A. 2010. A framework for the study of linguistics. Pretoria: Van Schaik.

WEIDEMAN, A. 2011. Straddling three disciplines: foundational questions for a language department. Acta varia, 2011(1):1-21. (D.F. Malherbe memorial lecture and inaugural address, University of the Free State.)

WELLEK, R. \& WARREN, A. 1949. Theory of literature. New York: Harcourt Brace.

\section{Key concepts:}

coherence.

discourse types

poetic language

text

\section{Kernbegrippe:}

koherensie

poëtiese taalgebruik

teks

vorms van diskoers 
